\title{
REVITALIZATION OF ENERGY SUPPLY SYSTEMS IN THE SCALE OF A TOWN, A DISTRICT AND AN ISLAND
}

\author{
Justyna JUCHIMIUK ${ }^{1}$ \\ University of Zielona Gora, Zielona Góra, Poland
}

\begin{abstract}
Model actions undertaken in HafenCity and Wilhelmsburg during IBA Hamburg 200613 as well as energy transformation of Danish island of Sams $\varnothing$ towards self-sufficiency are examples of the use of energy as one of the key factors in the design of revitalization process in various scales. An important issue is to determine the impact of renewable energy systems on design process, architecture and urbanism of revitalized structures. Article examines the programs and projects related to the processes: renewal of degraded inner-industrial areas (brownfields), ecological restoration of degraded land, the revitalization of port and underdeveloped areas in the aspects of climate protection, the use of energy from renewable sources and improvement of technical conditions of building substance while maintaining the principles of sustainable development.
\end{abstract}

Keywords: energy regeneration, brownfields, waterfronts, IBA, RES, energy efficiency, energy transformation - Energiewende, prosumer energy generation.

\section{RENEWABLE SOURCES OF ENERGY IN THE REVITALIZATION PROCESS: HAMBURGS ENERGIEWENDE AND SAMSØ 2.0}

Transformation of energy systems undertaken by West European countries aims at economic independence from fossil fuels by increasing energy efficiency of their building substance, as well as at obtaining the greatest possible self-

\footnotetext{
${ }^{1}$ Corresponding author: University of Zielona Góra, Faculty of Building, Architecture and Environmental Engineering, Department of Architecture and Urban Planning, Z. Szafrana st 1, 65-516 Zielona Góra, Poland, e-mail: jjuchimiuk@gmail.com, tel.+48509041967
} 
sufficiency based on renewable energy sources. Hamburg, the European Green Capital of 2011, implemented a number of initiatives related to climate protection, e.g. long-term projects in Wilhelmsburg - within the exhibition IBA 2006-2013, or the revitalization of HafenCity - lasting for 15 years. A Danish island, which launched Sams $\varnothing 2.0$ strategy, is also an example of targeted regeneration activities based on renewable energy, but unlike the metropolitan city of Hamburg - in a local scale, carried out with the state support and global cooperation.

\subsection{Internationalle Bauaustellung 2006-13 and Hamburgs Energiewende}

The transformation of energy systems in Hamburg - Hamburgs Energiewende, just as in the whole Federal Republic of Germany, aims at the increase in energy efficiency, building sustainable and smart urban power supply systems and renewable energy. The consistent implementation of urban policy described in documents Klimaschutzkonzept 2007 - 2012, Masterplan Klimaschutz 2013 and 2015, aims at transforming Hamburg into a German wind energy capital in 2020. Until today, 60 wind turbines supplying $50 \mathrm{MW}$ (ultimately - 100MW) have already been installed in this area.

In the field of renewable energy sources, 14.500 jobs have been created here, and within the metropolitan area - 24.700. City implements strategies for sustainable public transport combined with electric mobility. By 2025, a total number of 525.000 low-energy-consuming dwellings will be constructed there. As part of IBA Hamburg, the city opted for the revitalization of vast brownfields, ports and degraded "inner peripheries" on the islands of the river Elbe, while transforming their energy systems, included in the plans of selfsufficient Wilhelmsburg. An important issue, among the IBA initiatives, was a symbolic "crossing the river Elbe" - connecting the isolated islands with the rest of the city, while developing social and educational infrastructure. The revitalization of the downtown areas was carried out in line with the strategy of sustainable land management, which maintains the green areas of the city $[1,2]$.
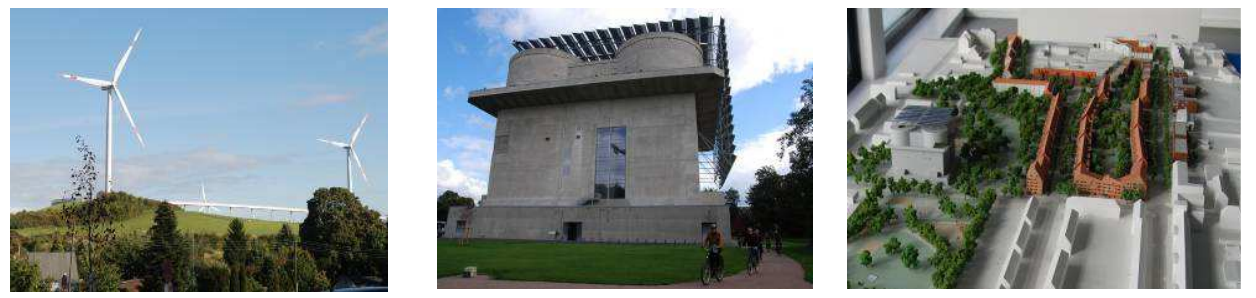

Fig. 1. Hamburg - Wilhelmsburg a) Energieberg Georgswerder b) Energiebunker,

c) Weltquartier model - revitalized settlement from the 1930s Source: own materials 

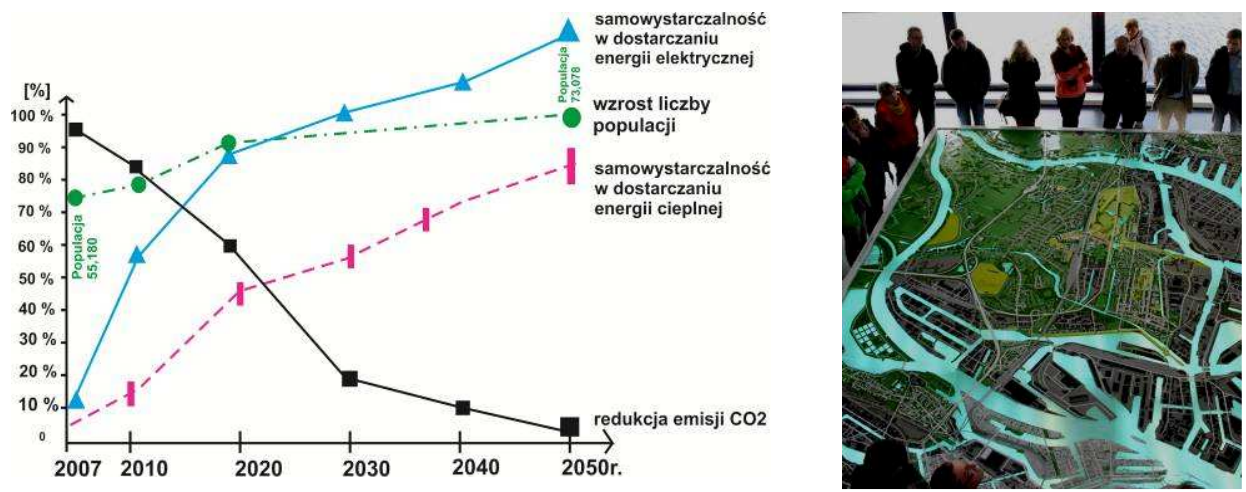

Fig. 2. Hamburg, a) a diagram of the concept of energy self-sufficiency - Wilhelmsburg 2050 Source: own elaborations and IBA data [1], b) a model of Wilhelmsburg demonstration projects of IBA_Hamburg 2006-13, Source: own materials

\subsection{A hill and a bunker of energy - IBA Hamburg, Wilhelmsburg}

The IBA activities include the program Hamburg 2006-13, connected with climate protection (renewable sources of energy including) fit into the longterm plan of the self-sufficient district, Wilhelmsburg 2020/30/50.

Energieberg Georgswerder - called "a hill of new horizons" - former 45-hectare landfill, after long-term safety and reclamation activities is an example of re-use of land, now publicly available. It represents a new educational and vantage point on the Hamburg map, as well as is an example project in the field of renewable energy with a "green power plant" for 4000 households in Wilhelmsburg district, applying 3 wind turbines, PV installation and heat pumps $[1,3]$.

Another IBA project is the "Energiebunker". It is regarded as a symbol of cogeneration of energy and activities related to protection against climate change. It is a former anti-aircraft bunker, subjected to a thorough modernization. It is planned to transform it into a supplier of thermal energy for 3,000 households and a producer of green electricity $(2.5$ million $\mathrm{kW} / \mathrm{h})$. The heart of the bunker is a water tank with a capacity of 2 million litres, which is a heat buffer for the district heating network and the building facade and roof are covered with a huge system of PV panels [1.2].

Thanks to the intelligent combination of various sources, energy production at this facility will constantly grow. In conjunction with Energieberg Georgswerder and other projects of the IBA and Hamburgs Energie Wende, it will completely meet the energy demand for Wilhelmsburg district, with the support of innovative smart grid technologies, virtual power plants and with the participation of the inhabitants - active energy prosumers . 


\subsection{Energy for Weltquartier and the Welt-Gewerbehof quarters - IBA}

IBA projects have a significant impact on the urban, functional and social structure of downtown areas of the city. The activities involving the modernization of built-up areas undertaken in Wilhelmsburg in Weltquartier and Welt-Gewerbehof create sustainable and attractive living environment and a workplace, in cooperation with the local community. Innovative systems using energy from renewable sources are relatively easy to integrate into newly constructed buildings for example Smart Material Houses - (model energyefficient buildings implemented under the IBA Bauauusstellung in der Bauausstellung) [2]. A more complex issue seems to be the adaptation of buildings from the 1930s, or their complexes, to the requirements of such systems. Buildings in the housing estates Wilhelmsburg and Prima KlimaAnlage Campanion were successfully subjected to comprehensive revitalization $[1,3]$.

\subsection{Revalorization of the urban landscape - Hamburg}

Changes in Hamburg concern also the implementation of the revalorization program of the urban landscape, which is based on the main axes of urban greenery and on urban landscape models, with the strengthened role of coastal green areas in the complex ecosystem of the metropolis on the river Elbe. Green areas and undeveloped spaces were incorporated into the landscape of largescale housing estates and quarters, also green rings were formed around the central districts. Currently, these areas and open public spaces occupy almost half of the city area [1]. As part of their fusion, the GrünesNetzHamburg project is implemented. It is a system of nice pedestrian and bike paths - as an alternative option of emission-free urban transport. Since 2015, the city has also been implementing the strategy regarding roofs, Gründach-Strategies, that combines urban sustainable development policy with the European objectives to adapt to climate change. Legal instruments and the incentive scheme with a budget of 3 million euros have been introduced to support the extensive planting on roofs, as well as PV and solar installations which generate green energy for the city prosumers.

\subsection{The revitalization of brownfield sites and wharfs - HafenCity}

HafenCity is referred to as one of the most important areas of the development of the coastal areas of Hamburg. Thanks to it, by 2025, the metropolis will expand its centre by nearly $40 \%$ and will get closer to the river Elbe. The enormous scale of the revitalization of brownfields ( 157 ha -126 ha of land and 31 ha of floating platforms) is based on public-private partnership seen by the 
city-land as a priority, which speeds up decision-making and execution processes, and also attracts a group of investors [6].

It is estimated that the project will cost approx. 10.4 billion $€(2.4$ billion $€-$ public funds, $8 \mathrm{mld} €$ - private investment) and 2.32 million $\mathrm{m} 2$ of residential and commercial areas will be built as well as green areas and open spaces, based on a five-level urban sustainable development strategy. The first of the levels is the efficient and sustainable use of so-called brownfields, which involves the change of their planned destination while maintaining the coastal tradition and flood protection. The next levels include the use of renewable energy and the implementation of a district heating network of a low-carbon index. They promote the short distance mobility, "walkable city", integrated (land and river) public transport. The last level is the individual building certification system - Ecolabel, taking into account environmental criteria of environmental sustainability, the use of renewable energy and energy efficiency [6].
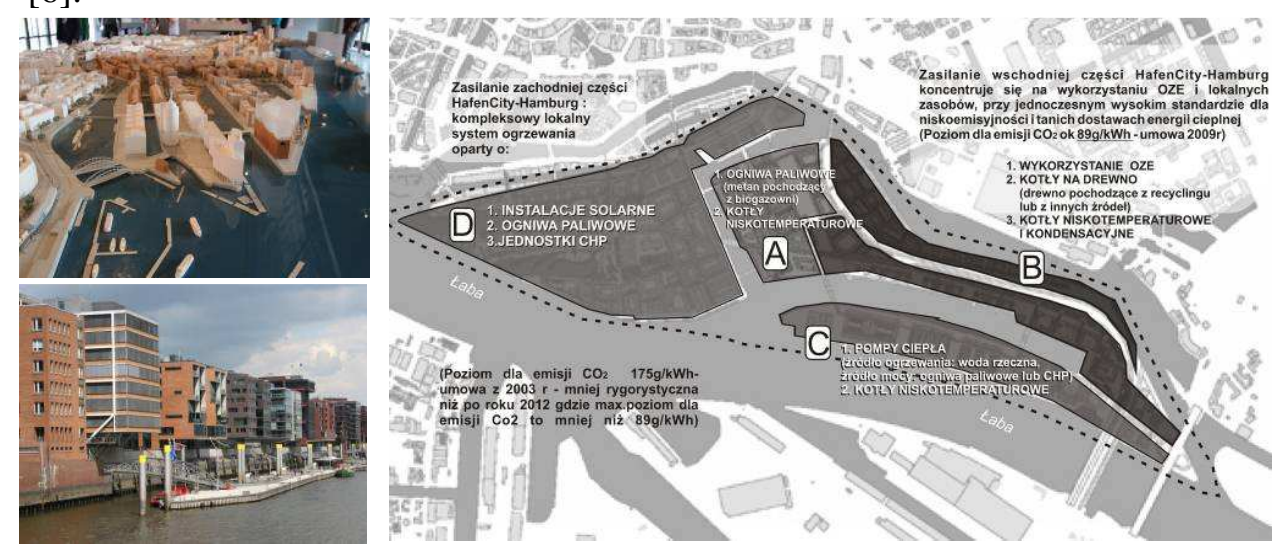

Fig. 3. Hamburg - HafenCity, a) a model of revitalization of 157 ha of land; b) realized residential and office buildings along MarcoPolo Promenade; c) map referring RES and energy efficiency with accepted standards of $\mathrm{CO} 2$ emission reduction, Sources: own photographs and elaborations based on data included in the Masterplan-HafenCity 2013 [6].

\section{EXPERIMENTS AND EXPLORATION - ISLAND OF SAMS}

What connects the metropolitan Hamburg with a small island Samsø is renewable energy and the transformation of energy systems on a massive scale (relating the whole community). This energetically self-sufficient Danish island is an example of a comprehensive use of RES in the revitalization of less urbanized areas. The applied multi-faceted solutions are based on the principles 
of sustainable development, taking into account social, economic (economic) and environmental objectives. The undertaken activities related to energy have been carried out since 1997. After winning a government competition for the use of renewable energy technologies while maintaining the landscape, a10-year program aiming at supplying $100 \%$ energy from the renewable energy. By switching to green renewable energy, Sams $\varnothing$ achieved independence of their decentralized energy system, new jobs for prosumers as well as an "eco-island" image on a global scale [5].

\subsection{Samsø 2.0.}

Sams $\varnothing$, as the first Danish island well balanced in terms of energy, and neutral in terms of $\mathrm{CO} 2$ emissions within the strategy Sams $\varnothing 2.0$, according to which the island strives to achieve complete independence from fossil fuels by 2030 . There were no social protests related to investments in energy. There were no NIMBY effects (not in my back yard), i.e. protests against launching energy projects in the area of residence, despite the general acceptance for the implemented idea. An opposite phenomenon seems to frequently occur, i.e. IMBY - "a windmill in my backyard". A total number of 11 wind turbines, owned by private investors or by local energy cooperatives - supply energy to the nearby households. There are 10 turbines (offshore type) operating at sea, and the excess energy is sold to the mainland. $75 \%$ of heat demand is produced in 4 professional heating plants. The construction of the heating plants was financed by the Danish Energy Authority, most of them belong to heat consumers, others are owned by the local company. By 2030, the island is planning to reduce thermal energy consumption in buildings by $33 \%$, and for the last 5 years all new houses (and the modernized ones) have been constructed as low-energy houses or passive houses 10. Other individual households use renewable energy installations and generate green energy as prosumers $[5,6]$.
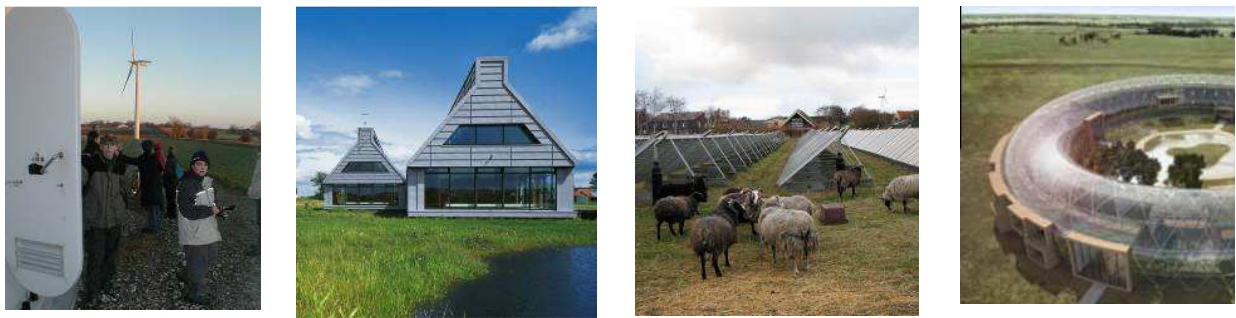

Fig. 4. The island Sams $\varnothing$-Denmark; a) one of the 11 wind turbines - co-ownership of a local cooperative; b) the facility of the Sams $\emptyset$ Energy Academy in Ballen; c) solar farm Nordby; d) a plan of Samsborg campus; Source: energyacademy.dk [5] 
Also agriculture is subject to restructuring into more organic, sustainable production, including energy crops, used for economically viable production of biogas, which is used in demonstration projects, i.e. the production of methanol or hydrogen for land and sea transport. Sams $\varnothing$ is an island of short distances, where experiments on intelligent power supply systems for e-cars, used as wind energy storage, the main means of transport on the island [4,5].

\subsection{Good practices and education of the local community}

Educational activities, training and collaboration with the local community on the promotion of the decentralized energy system are some of the tasks and projects implemented by the Sams $\phi$ Energy Academy. Its headquarters - a model facility, funded by local craftsmen, is a meeting place for local community and people interested in RES, co-operatives and the transformation of energy systems. Combined regeneration projects on the island opened possibilities of cooperation with educational institutions and companies from around the world. The adopted strategy of the development of Sams $\varnothing 2.0$ as well as the subsequent new projects expanding pro-environment activities need meeting space, on the island which is visited annually by more than 5000 guests [4]. It is planned to build an innovative campus Samsborg - space for for green education and sustainable tourism. The complex with a high standard of energy, known as "2025 passive plus", will offer activities based on the sustainable development strategy of the island. A number of initiatives undertaken include: energy production and its efficiency - energy which for years has united its inhabitants. One of them is Continue for yourself!, including any actions that result in reduced energy consumption in buildings or in the increased respect for energy resources in "your backyard", which in "our backyard", i.e. the entire island Sams $\varnothing$, brings a measurable success for its self-sufficiency [5].

\section{CONCLUSIONS}

Strategies for revitalization of problematic areas of Hamburg aiming at the transforming the city into a green and energetically balanced metropolis provide a comprehensive approach on several levels, taking into account the needs of participants in the process, effectively using available planning instruments, as well as legal and financial instruments in the assumed time horizon. Both shortterm and long-term projects give the future image of the city - a green metropolis, which struggles with the problems of degraded land, suburbanization, with the climate-change challenges as well as in the field of socio-cultural co-existence of many cultures. The undertaken in Hamburg attempts to reconcile the requirements of the energy systems transformation (Energiewende) with the latest trends in revitalization of the city seem to be an 
interesting direction to seek for a compromise between spatial planning and energy consumption and its urban sustainable production. In a smaller, local scale, on the Danish island, the first stage of such changes has already been completed - Sams $\varnothing$ achieved energetic self-sufficiency. Currently, version 2.0 is being realized, i.e. the idea of an island free from fossil fuels, taking advantage of their neighbours' good practices.

\section{REFERENCES}

1. Hellweg U.(ed), IBA Hamburg: Energy Atlas - Future Concept Renewable Wilhelmsburg, Hamburg, Jovis Verlag GmbH i IBA Hamburg GmbH 2010.

2. Hellweg U.(ed), IBA Hamburg (Hrsg.): Netzwerk IBA meets IBA - Zur Zukunft Internationaler Bauausstellungen, Hamburg, Jovis Verlag GmbH i IBA Hamburg GmbH, 2010.

3. Hellweg U.(ed), IBA Hamburg (Hrsg.): IBA Hamburg: Projekte und Konzepte, Katalog zur Zwischenpräsentation, Berlin, JOVIS Verlag 2010.

4. Larsen M.: Samsø 2.0, Community-Sams $\varnothing$ Energy Academy (2013)18-21.

5. Larsen G.:From best to next practice, Community- Samsø EA(2013)26-27.

6. HafenCity - Masterplan 2000 i 2012,www.hafencity.com (08.01.15r.).

\section{ENERGETYCZNA REWITALIZACJA W SKALI MIASTA, DZIELNICY I WYSPY}

\section{Streszczenie}

Modelowe działania podejmowane w HafenCity oraz te w ramach IBA-Hamburg 20062013 w Wilhelmsburgu jak również transformacja duńskiej wyspy Samsø w samowystarczalną energetycznie mogą stanowić przykłady wykorzystania OZE jako jednego z czynników w projektowaniu procesu rewitalizacji w różnych jej skalach. Istotnym wydaje się określenie wpływu, jaki wywierają systemy wykorzystujące OZE na proces projektowy,architekturę i urbanistykę rewitalizowanych struktur. Artykuł poddaje analizie programy $\mathrm{i}$ projekty związane $\mathrm{z}$ procesami: odnowy zdegradowanych, poprzemysłowych, rekultywacji terenów zdegradowanych ekologicznie, rewitalizacji obszarów portowych i słabo zurbanizowanych w aspektach ochrony klimatu, zastosowania energii ze źródeł odnawialnych, efektywności energetycznej oraz poprawy warunków technicznych obiektów przy zachowaniu zasad rozwoju zrównoważonego.

Słowa kluczowe: rewitalizacja, brownfields, nabrzeża, IBA, OZE, efektywność energetyczna, Energiewende, energetyka prosumencka. 